\title{
Dahi manufacturing from reconstituted skim milk partially replaced by coconut milk
}

\author{
SR Saha, MN I slam, AL Shekh, MSR Siddiki*
}

Department of Dairy Science, Bangladesh Agricultural University, Mymensingh 2202, Bangladesh

\begin{abstract}
The present study was conducted to investigate the feasibility of using coconut milk by replacing reconstituted skim milk for Dahi manufacturing. Reconstituted skimmed milk was replaced by $0,10,20$, and $30 \%$ coconut milk to produce Dahi designated as A, B, C and D. All the samples were analyzed for organoleptic, chemical and microbiological qualities. According to organoleptic test, the overall highest score was observed in sample B $(84.37 \pm 1.64)$ and the lowest score was found in sample D (75.0 1.41$)$. In all levels of replacement increased fat, carbohydrates, ash and total solids were obtained, while moisture and protein content were significantly decreased in Dahi samples. Acidity and $\mathrm{pH}$ of all the treatments were significantly influenced and ranged from 0.65 to $0.73 \%$ and 4.21 to 4.57 , respectively. Ash content of all samples was not significantly increased. Total viable count of reconstituted Dahi samples (B, C and D) was significantly increased. It could be concluded that 10 and $20 \%$ replacement of reconstituted skim milk with coconut milk for the manufacture of Dahi was acceptable and reduced the production cost, but $10 \%$ replacement was better in compare to others, according to organoleptic, chemical and microbiological analysis.
\end{abstract}

Key words: reconstituted, skim milk, coconut milk, organoleptic.

Bangladesh Animal Husbandry Association. All rights reserved. Bang. J. Anim. Sci. 2014 . 43 (3): 218-223

\section{I ntroduction}

Dahi is the curd resulting from the lactic fermentation of milk and one of the most popular fermented product of Bangladesh and others neighboring countries obtained through an anaerobic fermentation of lactose in milk by relevant microorganisms most of which are classified as pro-biotic (Tull 1996) The microorganisms, which are responsible for the fermentation of lactose in milk are Streptococcus thermophilus, S. lactis, Lactobacillus acidophillus, L. bulgaricus. Along with taste, Dahi has many health benefits such as maintaining bone and dental health, fluid balance in body, facilates and monitor reproductive health, relief from constipation, cardiovascular diseases, colon cancer, diarrhea, inflammatory bowel syndrome etc. (Agarwal et al. 2001). Dahi prepared from cow milk is most popular in Bangladeshi market. The principal ingredient that is usually used for the preparation of this type of Dahi is evaporated whole milk or fresh milk from cow. Although this milk produces good quality Dahi, there are certain limitations that make it difficult for the ordinary Bangladeshi middle income earner to buy it. This is because the evaporated whole milk or fresh milk from cow is relatively expensive compared with other possible sources which have the potential to produce same type of Dahi like cow milk. On the other hand, the milk production of our country is not satisfactory. For this reason the sweetmeat makers cannot produce enough Dahi all the year round. Skim milk powder is available in our country due to low price compared to whole milk. Reconstituted skim milk could easily be prepared by mixing desired amount of water. But we should bear in mind that skimmed milk powder has no fat and we also realized that strict vegetarians and most of the health conscious people are also like to avoid animal fat. This factor has made vegetable milk to become an alternative source of milk. Coconut is highly accepted by the consumer due to its high calorific and nutritive value. Coconut milk was reported to be high in mineral and vitamins (Nieuwentus and Nieeuwelink, 2002) while total saturated fat was $10 \%$ of total energy (Thai Food Composition, 2004). In this point of view, we can use coconut milk as a fat source as it contains high concentration of vegetable fat. It is therefore 
of great importance to find out the feasibility of using the coconut milk as substrate for Dahi production (Belewu and Belewu, 2007). In the light of the above, this research was taken to observe the feasibility of using of skim milk powder and coconut milk in the production of Dahi and also cost effective.

\section{Materials and Methods}

The experiment was conducted at the Dairy Chemistry and Technology and Dairy Microbiology Laboratory of the Department of Dairy Science, Bangladesh Agricultural University, Mymensingh during the period from October to November 2013.

Coconuts were purchased from the local market. The edible portion (cellular endosperm) of coconut was shredded carefully to avoid the waste material. Two cups of warm water $(250 \mathrm{ml})$ for every cup of coconut were used to prepare coconut milk. The coconut and water were blended with high pressure until the mixture was as smooth as possible. When the blending was completed then the coconut milk was filtered by a clean muslin cloth (hot water washed) and kept it in a beaker.

The skimmed milk powder was purchased from a grocery shop of Mymensingh town. When skimmed milk powder is dissolved with water then it may be defined as reconstituted skim milk. In this experiment the skimmed milk powder was added at the rate of $9 \mathrm{~g}$ per $100 \mathrm{ml}$ (w/vol) of warm water to prepare reconstituted skim milk.

For the preparation of different types of Dahi, either reconstituted skimmed milk or reconstituted skim milk samples partially replaced by 10,20 and $30 \%$ of coconut milk were taken in a pan and were heated in boiling temperature to reduce it's volume up to $20-25 \%$. During the time of boiling about $12 \%$ sugar was added with each milk sample. At the time of boiling the milk samples were stirred thoroughly by using stirrer and then the milk pans were removed from the heater and allowed to cool down and when the temperature was reached at about $42^{\circ} \mathrm{C}$, then the mixed starter culture was added with each sample at the rate of $2 \%$. Annatto seeds were used as coloring agent. Then the warm milk of $42^{\circ} \mathrm{C}$ was poured into several pre-washed plastic cups after the inoculation and then the Dahi sample were transferred into incubator for coagulation. After 4 hours when the coagulation was completed, then the Dahi samples were taken out from the incubator and the samples were transferred into refrigerator. The refrigerator temperature was $5^{\circ} \mathrm{C}$.

Organoleptic evaluation was performed by eight member expert panel of judges using a 100point scale (Smell and taste score: 50 , body and consistency score: 30, color and texture score: 20).

Chemical analysis (fat, acidity, $\mathrm{pH}$, protein, moisture, carbohydrate, ash) of coconut milk, and reconstituted skim milk samples were performed before the preparation of Dahi to determine the initial quality. Dahi samples were analyzed chemically for parameters mentioned above. Quevenne lactometer (Kimble Glass Co. USA) was used for the determination of specific gravity of the milk samples (Aggarwala and Sharma, 1961). Total solids and moisture content of the milk samples were estimated by oven (Vulcan A-550 Furnace, USA) drying method ( $105^{\circ} \mathrm{C}$ for 24 hours) (AOAC 2003). Babcock method was used for the determination of fat content of reconstituted skimmed milk (Aggarwala and Sharma 1961). The fat content of coconut milk was determined by using ether extract method. Kjeldahl procedure was used for the determination of crude protein. Acidity of milk samples were determined by titration with $0.1 \mathrm{~N}$ $\mathrm{NaOH}$ (Aggarwala and Sharma 1961). The $\mathrm{pH}$ was measured by using a pH meter-215 (Ciba Coming Diagnostics Limited, Suffolk, England Co.). Ash was determined by the incineration method according to AOAC (2003).

To determine the total bacterial count of Dahi samples, standard plate count (spc) were performed according to the procedure described in "Standard Methods for Examination of Dairy Products" (American Public Health Association, 1998). Coliform count of the Dahi samples were also performed according to the method as described in the "Standard Methods for Examination of Dairy Products" (APHA 1998). 


\section{Coconut milk in Dahi manufacturing}

Data which were collected from this experiment were subjected to statistical analysis to make difference between treatments. Analysis of variance (ANOVA) was performed to observe the statistical difference between the treatments. All experimental materials were completely homogenous in this experiment. For this reason collected data of this experiment were analyzed by using one way analysis of variance test (CRD) with SPSS statistical package. In case of significant differences least significant difference (LSD) was performed to observe the significant differences within treatment means.

\section{Result and Discussion}

The initial quality of reconstituted skim milkand coconut milk was determined by conducting different types of chemical analysis in laboratory before preparation of Dahi (Table 1). The average chemical component of the experimental reconstituted skim milk (Habib et al., 2004 and Begum et al. 2011) and coconut milk (Law et al. 2009) sample (Table 1) was within normal ranges. So the results listed in the Table 1 indicated that the experimental reconstituted skim milk and coconut milk sample was acceptable.

The quality of different types of Dahi sample was analyzed by conducting various organoleptic, chemical and microbiological tests. Organoleptic scores are given in the Table 2 . Smell and taste score of Dahi samples having $0,10,20$ and $30 \%$ coconut milk were significantly varied $(p<0.01)$. The highest value was seen in sample 'B' Dahi followed by C, A and $D$ and the lowest score was recorded in sample ' $D$ '. The variation in smell and taste score of Dahi usually depends on type of milk, starter culture and manufacturing process involved (Ali et al. 2002). There were significant difference obtained within the samples for body and consistency score $(p<0.05)$. It was also found that the body and consistency score of Dahi 'B' ( $10 \%$ coconut milk) and Dahi ' $C$ ' (20\% coconut milk) were higher than that of Dahi ' $D$ ' (30\% coconut milk).

The color and texture score of different types of Dahi samples are presented in Table 2 . Statistical analysis showed that there were significant difference within the samples for color and texture score $(p<0.05)$. The highest color and texture score of Dahi is observed in case of Dahi ' $B$ ' and was followed by " $C$ " and "D". Statistical analysis showed that significant difference existed among the overall score of Dahi samples $(p<0.01)$ (Table 2$)$. Highest score was obtained by ' $B$ ' sample followed by ' $A$ ', ' $C$ ' and ' $D$ ' and the lowest score obtained by ' $D$ ' sample, but they are in acceptable level. This result agrees with the finding of Hossain et al. (2008).

Table 1. Chemical composition of experimental reconstituted skim milk and coconut milk sample

\begin{tabular}{ccccccccccc}
\hline Type & SG & TS & Fat & Protein Lactose & Ash & SNF & $\begin{array}{c}\text { Acidity } \\
\%\end{array}$ & $\begin{array}{c}\text { pH } \\
\text { value }\end{array}$ \\
\cline { 3 - 8 } & \multicolumn{9}{c}{ valkg } \\
\hline SM & 1.04 & 81.56 & 1.10 & 30.06 & 43.50 & 7.10 & 79.91 & 0.13 & 6.40 \\
& \pm 0.00 & \pm 1.15 & \pm 0.87 & \pm 0.81 & \pm 0.54 & \pm 0.18 & \pm 1.5 & \pm 0.12 & \pm 0.08 \\
\hline CM & 1.02 & 324.51 & 231.10 & 23.40 & 62.65 & 7.50 & 93.52 & 0.11 & 6.30 \\
& \pm 0.00 & \pm 0.87 & \pm 4.50 & \pm 2.04 & \pm 4.54 & \pm 0.18 & \pm 0.65 & \pm 0.10 & \pm 0.07 \\
\hline
\end{tabular}

SG, specific gravity; TS, total solids; SM, skimmed milk; CM, coconut milk

Table 2. Organoleptic score for Dahi samples prepared from reconstitute skimmed milk and its partial replacement with coconut milk

\begin{tabular}{|c|c|c|c|c|c|}
\hline \multirow{2}{*}{ Quality attributes } & \multicolumn{4}{|c|}{ Types of Dahi } & \multirow{2}{*}{$\begin{array}{l}\text { Sig. } \\
\text { level }\end{array}$} \\
\hline & A & $B$ & $\mathrm{C}$ & $\mathrm{D}$ & \\
\hline \multirow{2}{*}{ Smell and Taste } & $40.03^{b}$ & $42.63^{a}$ & $40.27^{b}$ & $38.77^{b}$ & \multirow{2}{*}{ ** } \\
\hline & \pm 0.55 & \pm 1.00 & \pm 0.93 & \pm 0.93 & \\
\hline \multirow{2}{*}{ Body and Consistency } & $24.52^{a b}$ & $25.63^{a}$ & $22.7 \mathrm{bc}$ & $21.36 c$ & \multirow{2}{*}{ * } \\
\hline & \pm 0.92 & \pm 1.27 & \pm 0.75 & \pm 2.05 & \\
\hline \multirow{2}{*}{ Color and Texture } & $15.66^{\mathrm{bc}}$ & $16.10^{\mathrm{a}}$ & $15.87^{b}$ & $14.89 \mathrm{c}$ & \multirow{2}{*}{ * } \\
\hline & \pm 0.43 & \pm 0.53 & \pm 0.55 & \pm 0.19 & \\
\hline \multirow{2}{*}{ Total score } & $80.21^{b}$ & $84.37^{a}$ & $78.90^{\mathrm{b}}$ & $75.00^{c}$ & \multirow{2}{*}{ ** } \\
\hline & \pm 0.78 & \pm 1.64 & \pm 0.36 & \pm 1.41 & \\
\hline
\end{tabular}

A: $100 \%$ reconstituted skim milk; B: $10 \%$ coconut milk; C: $20 \%$ coconut milk; D: 30\% coconut milk; Means with different superscripts in the same row differed significantly; ${ }^{*}, p<0.05 ;{ }^{*}, p<0.01$

The average acidity percentage and $\mathrm{pH}$ of Dahi samples (A, B, C, and D) varied significantly $(p<0.05)$. Mean percentage of acidity was highest in sample ' $D$ ' and lowest in sample ' $A$ '. Acidity increased slightly due to the addition of different levels of coconut milk. This result agrees with the report of Hossain et al. (2008). 
Saha et al. (2014) Bang. J. Anim. Sci. 43 (3): 218- 223

However, average $\mathrm{pH}$ value was highest in sample ' $A$ ' and lowest in sample ' $D$ '. Addition of coconut milk slightly decreased the $\mathrm{pH}$ value of Dahi. It is well known that when $\mathrm{pH}$ values decrease then acidity value will increase. It is well known that when $\mathrm{pH}$ values decrease then acidity value will increase. Kosikowski et al. (1966) reported that the $\mathrm{pH}$ of normal Dahi samples should be approximately 4.4 which nearly agree with the present findings.

The total solids content of A, B, C and D types of Dahi samples were listed in the Table 3. Statistical analysis showed that there were significant differences within different types of Dahi samples for the total solids and moisture content $(p<0.01)$. Total solids content was highest in sample Dand followed by sample $C$ and sample $B$ and the lowest value was found in the sample ' $A$ ' (control). Whereas highest moisture content was observed in sample ' $A$ ' and the lowest was in the sample ' $D$ '. Addition of coconut milk increases the total solids content of Dahi. This result also agrees with the report of Hossain et al. (2008). Gupta et al. (1993) said that overall texture was significantly correlated with moisture content.

Table 3. Chemical composition of Dahi samples prepared from reconstitutes skimmed milk and its partial replacement with coconut milk

\begin{tabular}{|c|c|c|c|c|c|}
\hline \multirow{2}{*}{ Parameters } & \multicolumn{4}{|c|}{ Types of Dahi } & \multirow{2}{*}{$\begin{array}{l}\text { Sig. } \\
\text { level }\end{array}$} \\
\hline & $A$ & B & C & D & \\
\hline \multirow{2}{*}{$\begin{array}{l}\text { Total solid } \\
(\mathrm{g} / \mathrm{kg})\end{array}$} & $206.63^{d}$ & $233.40^{c}$ & $257.60^{b}$ & $280.38^{a}$ & \multirow{2}{*}{$\star \star$} \\
\hline & \pm 3.20 & \pm 5.50 & \pm 4.6 & \pm 4.70 & \\
\hline \multirow{2}{*}{$\begin{array}{l}\text { Moisture } \\
(\mathrm{g} / \mathrm{kg})\end{array}$} & $793.70^{a}$ & $772.90^{b}$ & $750.30^{c}$ & $726.80^{d}$ & \multirow{2}{*}{ ** } \\
\hline & \pm 3.20 & \pm 6.40 & \pm 9.8 & \pm 15.40 & \\
\hline \multirow{2}{*}{$\begin{array}{l}\text { Protein } \\
(\mathrm{g} / \mathrm{kg})\end{array}$} & $31.30^{a}$ & $29.60^{b}$ & $29.00^{b}$ & $28.60^{b}$ & \multirow{2}{*}{ ** } \\
\hline & \pm 0.46 & \pm 0.50 & \pm 0.61 & \pm 0.78 & \\
\hline \multirow{2}{*}{ Fat(g/kg) } & $1.10^{d}$ & $22.00^{c}$ & $43.60^{b}$ & $65.50^{a}$ & \multirow{2}{*}{ ** } \\
\hline & \pm 0.32 & \pm 0.61 & \pm 0.90 & \pm 2.34 & \\
\hline \multirow{2}{*}{$\begin{array}{l}\text { Carbohy } \\
\text { drate(g/kg) }\end{array}$} & $167.10^{b}$ & $174.70^{b}$ & $177.60^{a}$ & $182.00^{a}$ & \multirow[b]{2}{*}{ * } \\
\hline & \pm 2.3 & \pm 5.80 & \pm 4.5 & \pm 4.30 & \\
\hline \multirow{2}{*}{ Ash(g/kg) } & 6.80 & 10. & 7.40 & 7.70 & \multirow{2}{*}{ NS } \\
\hline & \pm 0.3 & 1.1010 .02 & \pm 0.46 & \pm 0.36 & \\
\hline \multirow{2}{*}{ Acidity(\%) } & $0.65^{b}$ & $0.69 a b$ & $0.71^{a}$ & $0.73^{a}$ & \multirow[t]{2}{*}{ * } \\
\hline & \pm 0.035 & \pm 0.035 & \pm 0.02 & \pm 0.02 & \\
\hline \multirow{2}{*}{$\mathrm{pH}$ value } & $4.57^{a}$ & $4.44 \mathrm{ab}$ & $4.35^{a b}$ & $4.21^{b}$ & \multirow[t]{2}{*}{ ‡ } \\
\hline & \pm 0.208 & \pm 0.147 & \pm 0.052 & \pm 0.006 & \\
\hline
\end{tabular}

A; $100 \%$ reconstituted skim milk; B: $10 \%$ coconut milk; C: $20 \%$ coconut milk; D: $30 \%$ coconut milk; Means with different superscripts in the same row differed significantly; *, $p<0.05$; ${ }^{*}, p<0.01 ; N S$, not significant
Significant differences was found for fat and protein content of different types of Dahi samples $(p<0.01)$. Highest fat and protein percentage was observed in sample " $D$ " $(30 \%$ coconut milk) and lowest was in the sample ' $A$ ' (control). Due to high fat content in coconut milk, fat content of different Dahi samples increase with the addition of different levels of coconut milk. Addition of nonfat dry milk and vegetable oil also improve the total solids, fat and protein content of Dahi samples (Munzur et al. 2004). This result also agrees with the finding of Hossain et al. (2008).

The value of carbohydrate content of different Dahi samples (A, B, C and D) were statistically significant $(p<0.05)$, whereas there was no significant difference for ash content among the samples. The highest carbohydrate and ash percent was observed in sample ' $D$ ' and the lowest value was observed in sample ' $A$ ' (control). It was observed that carbohydrate percent gradually increased due to the addition of different levels of coconut milk for manufacturing Dahi which agrees with the result of Hossain et al. (2008).

Table 4. Microbiological evaluation of different Dahi samples

\begin{tabular}{lcccc}
\hline Parameters & \multicolumn{4}{c}{ Types of Dahi } \\
\cline { 2 - 5 } & A & B & C & D \\
\hline Total viable count $\mathrm{cfu} / \mathrm{g}\left(\times 10^{5}\right)$ & $8.07^{\mathrm{a}}$ & $8.27^{\mathrm{a}}$ & $8.40^{\mathrm{a}}$ & $8.77^{\mathrm{b}}$ \\
\hline Coliform count $\mathrm{cfu} / \mathrm{ml}$ & $\mathrm{Nil}$ & $\mathrm{Nil}$ & $\mathrm{Nil}$ & $\mathrm{Nil}$ \\
\hline
\end{tabular}

A: $100 \%$ reconstituted skim milk; B: $10 \%$ coconut milk; C: $20 \%$ coconut milk; D: $30 \%$ coconut milk; Means with different superscripts in the same row differed significantly $(p<0.05)$

The average total viable count $\mathrm{cfu} / \mathrm{ml}$ of Dahi samples were listed in Table 4. Statistical analysis showed that there was significant $(p<0.05)$ differences among the different types of Dahi samples. Highest total viable count/g was recorded for $D$ type Dahi sample and lowest value was recorded for ' $A$ ' type Dahi. There was no existence of any coliform bacteria in any Dahi samples. The presence of coliform bacteria indicates unhygienic conditions of Dahi preparation. Coliform bacteria are usually present in fecal materials contaminated water and feed stuffs used for livestock feeding. In the present study, to avoid contamination strict hygienic measure was taken. 
Table 5. Cost (taka) for different types of Dahi prepared in the laboratory

\begin{tabular}{|c|c|c|c|c|c|}
\hline Item & Amount & $\begin{array}{l}\text { Cost for } \\
\text { (A) }\end{array}$ & $\begin{array}{l}\text { Cost for } \\
\text { (B) }\end{array}$ & $\begin{array}{l}\text { Cost for } \\
\text { (C) }\end{array}$ & $\begin{array}{l}\text { Cost for } \\
\text { (D) }\end{array}$ \\
\hline \multirow{4}{*}{ Cow milk } & $600 \mathrm{ml}$ & 20.0 & & & \\
\hline & $540 \mathrm{ml}$ & & 18.0 & & \\
\hline & $480 \mathrm{ml}$ & & & 16.0 & \\
\hline & $420 \mathrm{ml}$ & & & & 14 \\
\hline \multirow{3}{*}{ Coconut milk } & $60 \mathrm{ml}$ & & 1.12 & & \\
\hline & $120 \mathrm{ml}$ & & & 2.24 & \\
\hline & $180 \mathrm{ml}$ & & & & 3.36 \\
\hline Sugar $(12 \%)$ & $72 \mathrm{~g}$ & 1.4 & 1.4 & 1.4 & 1.4 \\
\hline Starter culture & $10 \mathrm{~g}(2 \%)$ & 0.5 & 0.5 & 0.5 & 0.5 \\
\hline Plastic cup & 4 pieces & 5.5 & 5.5 & 5.5 & 5.5 \\
\hline Electricity cost & $0.6 \mathrm{~kg}$ & 1.0 & 1.0 & 1.0 & 1.0 \\
\hline Fuel cost & $0.6 \mathrm{~kg} 1.5$ & 1.5 & 1.5 & 1.5 & 1.5 \\
\hline Labor cost & $0.6 \mathrm{~kg}$ & 2.0 & 2.0 & 2.0 & 2.0 \\
\hline Depreciation cost & $0.6 \mathrm{~kg}$ & 1.0 & 1.0 & 1.0 & 1.0 \\
\hline \multicolumn{2}{|c|}{ Minimum cost for $0.6 \mathrm{~kg}$ Dahi } & 33.4 & 32.52 & 30.24 & 29.36 \\
\hline \multicolumn{2}{|c|}{ Minimum cost for $1 \mathrm{~kg}$ Dahi } & 55.6 & 54.2 & 50.4 & 48.9 \\
\hline \multicolumn{2}{|l|}{ Vat $(1.5 \%)$} & 1.0 & 1.0 & 1.0 & 1.0 \\
\hline \multicolumn{2}{|c|}{ Transportation cost } & 2.0 & 2.0 & 2.0 & 1.5 \\
\hline \multicolumn{2}{|c|}{ Total cost of production } & 58.6 & 57.2 & 33.4 & 51.4 \\
\hline
\end{tabular}

A: $100 \%$ reconstituted skim milk; B: $10 \%$ coconut milk; C: $20 \%$ coconut milk; D: $30 \%$ coconut milk

The production cost for per kg laboratory made 'A' type (control) Dahi was 58.6 taka, 'B' type (10\% coconut milk) was 57.2 taka, ' $C$ ' type ( $20 \%$ coconut milk) was 53.4 taka, and 'D' type (30\% coconut milk) was 51.4 BDT. So, in comparison to laboratory made Dahi, benefit for per kg 'B' type Dahi was 1.4 taka, benefit for per $\mathrm{kg}$ ' $\mathrm{C}$ ' type Dahi was 5.2 taka and benefit for per $k g$ ' $D$ ' type Dahi was 7.2 taka.

\section{Conclusions}

On the basis of organoleptic, chemical and microbiological tests it was concluded that ' $B$ ' and ' $C$ ' type Dahi were better than others. From the overall result, it can be stated that score of ' $\mathrm{B}$ ' and ' $C$ ' types' Dahi are also within acceptable range which appears that replacement of reconstituted skimmed milk with coconut milk at the rate of $10 \%$ and $20 \%$ may be used. Replacement of reconstituted skimmed milk with coconut milk not only enriches the nutritive value of Dahi, but also it makes the product cheaper in comparison with reconstituted skimmed milk Dahi. If these types of Dahi are introduced in commercial sector, the production cost may be reduced and demand load on whole milk Dahi would be reduced.

\section{References}

Agarwal KN, Bhasin SK, Faridi MMA, Mathur M and Gupta S (2001). Lactobacilluscasei in the control of acute diarrhea - a pilot study. Indian Pediatrics. 38: 905-910.

Aggarwala AC and Shamra RM (1961). A Laboratory Manual of Milk Inspection. Asia Publishing House. Bombay, India.

Ali MY, Islam MA, Alam MJ and Islam MN (2002). Quality evaluation of laboratory made Dahi and Dahi available in local market in Mymensingh of Bangladesh. Pakistan J ournal of Biological Science, 5: 343-345.

American Public Health Association (1998). Standard Methods for the Examination of Dairy Products. 20 th Edn. American Public Health Association, Inc. New York, USA. P. 34- 62.

AOAC (2003). Official Methods of Analysis. $10^{\text {th }}$ Edition. Association of Official Agricultural Chemists. Washington DC, USA.

Begum J, Nahar A, Islam MN, Rahman MM (2011). Qualitative characteristics of Dahi prepared form non-fat-dry milk fortified with vegetable oil. Bangladesh Research Publications J ournal, 6: 35-45.

Belewu MA, Belewu KY (2007) Comparative physico-chemical evaluation of tiger-nut, soybean and coconut milk source. International J ournal of Agriculture Biology, 9: 785-87.

Gupta SK, Patil AA, Patil GR, Desai HK, Ghosh BC (1993). Texture studies on selected Indian dairy products: composition, texture relationship. International Dairy J ournal, 5: 234-240.

Habib R, Hassan MN, Khan MAS, Islam MN, Hasan T (2004). Preparation of Dahi from cow milk and powdered milk by using singe bacterial culture of Lactobacillus acidophilus. Bangladesh Journal of Animal Science, 33: 101-110.

Hossain MA, Wadud A, Khan MAS, Islam MA, Matubbar A (2008). Preparation of Dahi from cow milk adding of coconut milk. 
Saha et al. (2014) Bang. J. Anim. Sci. 43 (3): 218- 223

Bangladesh Journal of Progressive Science and Technology, 6: 345-348.

Kosikowski FY, Mistry VV, Kosikowski FV (1997). Cheese and Fermented Milk Foods. I thaca, New York, USA.

Law HY, Ong $\mathrm{Cl}$, Aziz NA, Taip FS, Muda N (2009). Preliminary work on coconut milk fouling deposits study. International Journal of Engineering \& Technology, 9: 10.

Munzur MM, Islam MN, Akhter S, Islam MR (2004). Effects of different levels of vegetables oil for the manufacture of Dahi from skim milk. Asian-Australian J ournal of Animal Science, 17: 1019-1025.

Nieuwentus R, Nieuwelink J (2002). Agrodok Series No. 10, The Netherlands pp. 28-30.

Thai Food Composition (2004) Institute of Nutrition Mahidol University (INMU), Thailand p. 150.

Tull A (1996). Food and Nutrition, Oxford University Press. P. 109-111. 